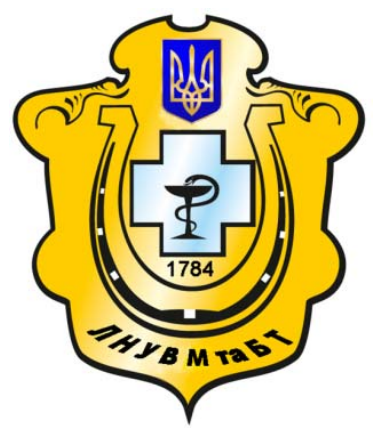

Науковий вісник Львівського національного університету ветеринарної медицини та біотехнологій імені С.3. Гжицького

Scientific Messenger of Lviv National University of Veterinary Medicine and Biotechnologies named after S.Z. Gzhytskyj

doi:10.15421/nvlvet7331

ISSN 2518-7554 print

ISSN 2518-1327 online

$\underline{\text { http://nvlvet.com.ua/ }}$

\title{
Епізоотологічний моніторинг бабезійної інвазії серед собак у Полтаві
}

\author{
Ю.О. Мокрий, І.М. Ксьонз \\ nabor_2008@i.ua, igor.ksyonz@ukr.net \\ Інститут свинарства та АПВ НААН, \\ вул. Шведська Могила, 1, м. Полтава, 36013, Украӥна
}

\begin{abstract}
Бабезіоз собак - кровопаразитарне захворювання, щцо викликається найпростішими роду Вареsіа. $С$ декілька збудників иього захворювання, але у переважнній більшості випадків етіологічним чинником захворювання собак $\epsilon$ Babesia сапіs. Переносниками захворювання є кліщі родів Dermacentor ma Ixodes. Передається збудник від кліша до собаки в процесі харчування паразита кров'ю тварини. Метою досліджень було визначення епізоотологічних особливостей бабезіозу в м. Полтава. В результаті проведеного епізоотологічного моніторингу бабезіозу собак за 9-річний період (з 2007 по 2016 рр.) з'ясовано сезонність, визначено статеву, вікову та породну залежність захворюваності собак. Матеріалом для дослідження слугували статистичні дані лікувальних закладів ветеринарної медицини. Діагноз на бабезіоз ставився за даними анамнезу й характерними клінічними проявами та підтверджувався результатами мікроскопічного виявлення бабезій у мазках крові, приготованих з периферійної крові й забарвлених за Романовським-Гімзою. За означений період було зареєстровано 7866 випадків захворювання собак на бабезіоз. Аналіз отриманих даних свідчить, щчо означена інвазія реєструється впродовж всього року, при иьому взимку випадки захворювання мають спорадичний характер, а також суттєве їх зниження у спекотні літні місяиі. Загалом відмічається виразна сезонна динаміка з двома піковими періодами: квітень, вересень-жовтень. Серед захворілих собак самиі переважають самок на 20\%. Найбільше захворюють собаки віком від 2 до 3 років (11,1-16\%). Визначено стійку тендениію, щчодо зниження сприйнятливості до бабезіозу з віком. Стосовно породного співвідношення - найбільше захворюють безпородні собаки (20,9\%) та німецькі вівчарки (13,9\%) й ротвейлери (7,5\%).

Ключові слова: бабезіоз собак, кровопаразитарне захворювання, інвазія, Babesia canis, Dermacentor canis, Ixodes ricinus, переносник, епізоотологічний моніторинг.
\end{abstract}

\section{Епизоотический мониторинг бабезиозной инвазии среди собак в Полтаве}

\author{
Ю.А. Мокрый, И.Н. Ксёнз \\ nabor_2008@i.ua, igor.ksyonz@ukr.net \\ Институт свиноводства и агропромышленного производства НААН, \\ ул. Шведская Могила, 1, г. Полтава, 36013, Украина
}

Бабезиоз собак - кровепаразитарное заболевание, вызываемое простейшими рода Babesia. Есть несколько возбудителей этого заболевания, но в подавляющем большинстве случаев этиологическим фактором заболевания собак является Babesia canis. Переносчиками заболевания являются клещи родов Dermacentor и Ixodes. Передается возбудитель от клеща к собаке в процессе питания паразита кровью животного. Целью исследований было определение эпизоотологических особенностей бабезиоза в г. Полтава. В результате проведенного эпизоотологического мониторинга бабезиоза собак за 9летний период (с 2007 по 2016) установлена сезонность, определены половая, возрастная и породная зависимость заболеваемости собак. Материалом для исследования послужили статистические данные лечебных учреждений ветеринарной медицины. Диагноз на бабезиоз ставился по данным анамнеза и характерным клиническим проявлениям, и подтверждался результатами микроскопического выявления бабезий в мазках крови, приготовленных из периферической крови и окрашенных по Романовскому-Гимзе. За указанный период было зарегистрировано 7866 случаев заболевания собак бабезиозом. Анализ полученных данных свидетельствует, что данная инвазия регистрируется в течение всего года, при этом зимой

Citation:

Mokryi,Yu.O., Ksyonz, I.M. (2017). Epizootology monitoring of babezial invasion among dogs in Poltava. Scientific Messenger LNUVMBT named after S.Z. Gzhytskyj, 19(73), 149-153. 
случаи заболевания имеют спорадический характер, а также существенное их снижение в жаркие летние месяиь. В общем отмечается отчетливая сезонная динамика с двумя пиковыми периодами апрель, сентябрь-октябрь. Среди заболевших собак самиы преобладают самок на 20\%. Больше всего заболевают собаки в возрасте от 2 до 3 лет (11,1-16\%). Определена устойчивая тенденция по снижению восприимчивости к бабезиозу с возрастом. Относительно породного соотношения - чаще всего заболевают беспородные собаки (20,9\%), немецкие овчарки (13,9\%) и ротвейлеры (7,5\%).

Ключевье слова: бабезиоз собак, кровепаразитарное заболевание, Babesia canis, Dermacentor canis, Ixоdes ricinus, nepeносчик, эпизоотологический мониторинг.

\title{
Epizootology monitoring of babezial invasion among dogs in Poltava
}

\author{
Yu.O. Mokryi, I.M. Ksyonz \\ nabor_2008@i.ua, igor.ksyonz@ukr.net
}

\begin{abstract}
Institute of Pig Breeding and Agroindustrial Production NAAS,
Shvedska Mohyla Str., 1, Poltava, 36013, Ukraine
\end{abstract}

\begin{abstract}
Babesiosis of dogs is a blood infestation disease caused by protozoa of Babesia genus. There are several causative agents of the disease, but in most cases, the etiological factor of dogs' disease is Babesia canis. The disease is transmitted by ticks of Dermacentor and Ixodes genera. Pathogen is transmitted from the tick to the dog in the process of the tick's eating the dog's blood. The aim of the research was to study babesiosis epizootology of dogs in Poltava. As a result of epizootology monitoring of babesiosis for the 9-years period (2007 to 2016), seasonality was established, gender, age and pedigree dependency of incidence in dogs was defined. Statistic data of Poltava veterinary medicine institutions served as the study material.

Diagnosis of babesiosis was determined based on the disease history, peculiar clinical symptoms and results of microscopic detection of Babesia in blood smears prepared from peripheral blood (ear vein) and Romanowsky-Hiemsa stained. Dog blood smear study was performed under the immersion system of $90 \times 10$ power light microscope. For the above mentioned period, 7866 cases of babesiosis in dogs have been recorded. Analysis of the data obtained shows that the said infestation has been recorded throughout the year, with winter cases being sporadic and their significant reduction being observed in hot summer months. In general, the distinct seasonal dynamics was defined with the two peak periods: April and September-October. Among the diseased dogs, males overwhelm females by $20 \%$.

The most susceptible to the disease are dogs aged from 2 to 3 years (11.1-16\%), less - animals of 5-8 years of age (6.2-7.5\%) and the least number of cases is recorded in dogs from 8 to 18 years of age (0.1-4.4\%), i.e. a steady tendency is traced of susceptibility to babesiosis reducing with age. Concerning the breed ratio, the most susceptible are mongrel dogs (20.9\%), German Shepherds (13.9\%) and Rottweilers (7.5\%). The prospect of further research is creation of the preventive measures strategy to minimize the incidence of babesiosis in dogs, on the basis of the obtained epizootic monitoring data. Finally, the 9-years study results present a scientific interest for parasitologists in human and veterinary medicine.
\end{abstract}

Key words: dog babesiosis, blood infestation disease, invasion, Babesia canis, Dermacentor canis, Ixodes ricinus, transmitter, epizootology monitoring.

\section{Вступ}

Бабезіоз собак - кровопаразитарне захворювання, що викликається найпростішими роду Babesia i передається кліщами родів Dermacentor та Ixodes. Iснує декілька видів збудників, але у переважнній більшості випадків етіологічним чинником захворювання собак $\epsilon$ Babesia canis. Передається збудник від кліща до собаки в процесі харчування останнього на тварині.

3 кожним роком проблема бабезіозу набуває більшої гостроти, що пов'язано, перш за все, зі зростанням кількості собак у приватних власників. Найбільше дана тенденція стосується великих міст. Питання вивчення епізоотології собак в Україні досліджувало багато вчених, серед яких необхідно відзначити роботи М.П. Пруса (Prus, 2000; Halat et al., 2000; Prus et al., 2002; Prus, 2006), В.Ф. Галата (Halat et al., 2000), O.В. Семенко (Semenko, 2007). У роботах вказаних вчених досліджується поширення бабезіозу у містах: Київ, Суми. При цьому визначалась сезонна, породна, вікова та статева динаміка захворюваності.

Метою досліджень було дослідження епізоотології бабезіозу в м. Полтава. Для досягнення поставленої мети необхідно було вирішити наступні завдання: зібрати статистичні дані щодо захворюваності на бабезіоз з лікувальних закладів ветеринарної медицини м. Полтава за 2007-2016 роки; провести аналіз захворюваності з урахуванням сезону, віку, породи i статі собак.

\section{Матеріал і методи досліджень}

Матеріалом для дослідження були статистичні дані лікувальних закладів ветеринарної медицини м. Полтава різної форми власності щодо кількості випадків захворювань собак на бабезіоз в період з 2007 по 2016 роки. Попередній діагноз на бабезіоз ставився за даними анамнезу та клінічними проявами, що характерні для даного захворювання. Остаточний діагноз встановлювався за результатами виявлення бабезій у мазках крові. Мазки виготовлялись 3 периферичної крові відібраної з вушної вени, забарвлювались за Романовським-Гімзою і досліджувались під імерсійною системою світлового мікроскопу у збільшенні 90×10 (Garcia et al., 2000; Bowman and Fogarty, 2003). Для проведення аналізу статистичних даних було використано можливості комп'ютерної програми Microsoft Excel 2016. 


\section{Результати та їх обговорення}

За даними ветеринарних лікувальних закладів міста Полтави всіх форм власності всього за період 3 2007 по 2016 роки, було зареєстровано 7866 випадків захворювання собак на бабезіоз.

Собаки хворіли на бабезіоз в усі пори року, але в зимовий період зустрічались лише спорадичні випадки. В інші місяці року кількість випадків захворювання собак бабезіозом була значно більшою, при цьому спостерігається виразна сезонна динаміка і два пікових періоди: квітень-травень, вересень-жовтень. Найбільша кількість захворювань бабезіозом в м. Полтава у весняний період припадає на квітень $(20,2-36,2 \%)$ та травень (15,5-24\%). Найменше випадків реєстрували протягом всього зимового періоду $(0,1-2,3 \%)$ та в літній період - у липні $(0,7-4,7 \%)$ та серпні $(1,1-3,4 \%)$ (рис. 1).
Основним фактором, від якого залежить поширення бабезіозу серед собак, є оптимальна для розвитку кліщів-переносників температура довкілля. На рисунку 2 представлені середньомісячні коливання температури довкілля у м. Полтава впродовж 20072016 років.

Помітне зниження кількості випадків захворюваності собак на бабезіоз у літні місяці, особливо в липні та серпні, на нашу думку, пов'язане 3 перевищенням температури довкілля над оптимальною для активності кліщів-переносників. Негативний вплив на активність кліщів також мають низькі температури навколишнього середовища.

Стосовно статевої належності, то серед захворілих собак, кількість самців на 20\% перевищує самиць (табл. 1).

У віковому розрізі найбільше захворілих собак було в групі з віком від 2 до 3 років (табл. 2).

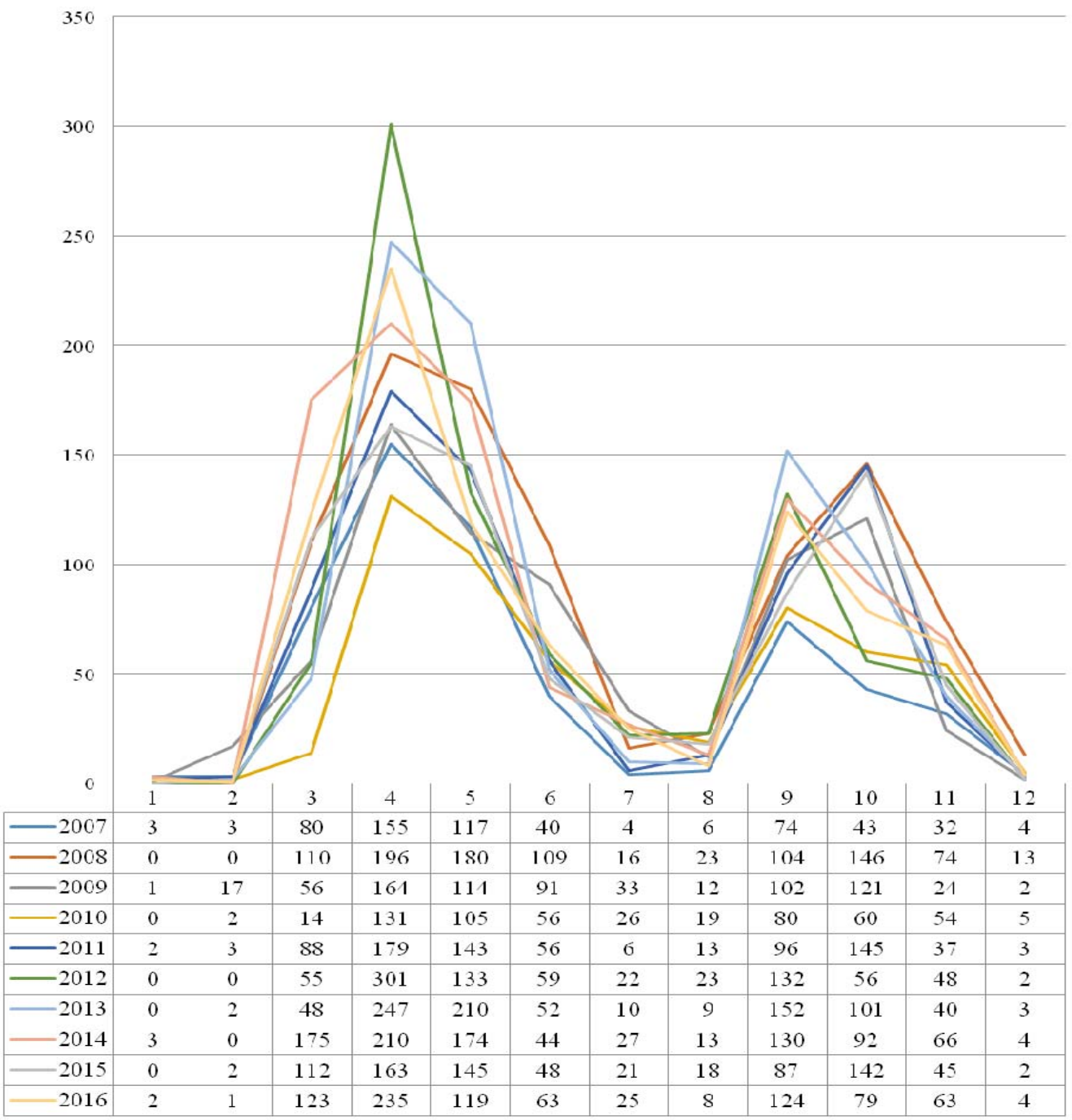

Рис. 1 Динаміка захворюваності собак на бабезіоз

3 даних, приведених у таблиці 2, відслідковується тенденція до зменшення захворюваності собак на бабезіоз з віком. Умовно, вікову сприйнятливість собак можна поділити на 3 вікових періоди, в яких йде досить значне зниження захворюваності цих тварин. Так, перший період, захворюваність собак в яко- му знаходиться в межах 11,1-16\% триває до 5 років; другий період триває від 5 до 8 років - захворюваність собак в цей період знаходиться в межах 6,27,5\% і третій період триває від 8 до 18 років, в якому захворюваність тварин мінімальна - 0,1-4,4\% випадків. 


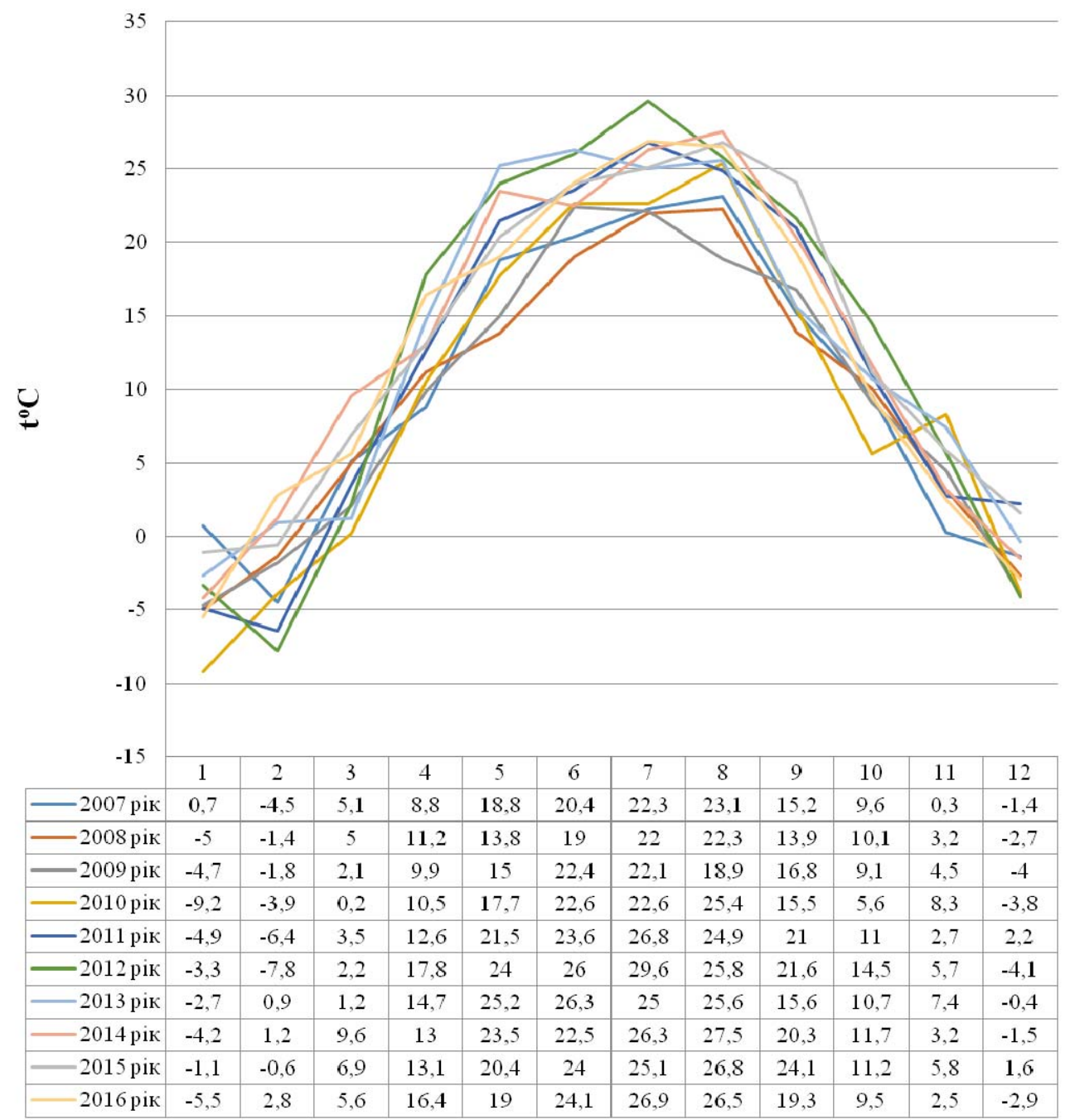

Рис. 2. Коливання середньомісячної температури довкілля (м. Полтава) за 2007-2016 рр.

Захворюваність собак на бабезіоз

Таблиия 1

залежно від статі

\begin{tabular}{|l|c|c|}
\hline Стать & Кількість & \% \\
\hline Самці & 4720 & 60 \\
\hline Самки & 3146 & 40 \\
\hline Всього & \multicolumn{2}{|c|}{7866} \\
\hline
\end{tabular}

Щодо захворюваності собак різних порід, найбільшу кількість хворих було зареєстровано серед представників породи німецька вівчарка $(13,9 \%)$ і ротвейлер (7,5\%). Також значну кількість випадків захворювання виявляли у собак порід: пекінес, середньоазіатська вівчарка, кавказька вівчарка, англійський кокерспанієль, пудель. Серед собак інших порід випадки захворювання спостерігаються значно рідше (табл. 3).

Найбільший же відсоток захворювань на бабезіоз реєструвався серед безпородних собак. При цьому слід відзначити, що летальні випадки серед таких собак були спорадичними.
Захворюваність собак на бабезіоз

Таблиияя 2 залежно від віку

\begin{tabular}{|c|c|c|}
\hline Вікова категорія & Кількість & $\%$ \\
\hline від 2 до 3 pp. & 1259 & 16 \\
\hline від 1 до 2 pp. & 1118 & 14,2 \\
\hline від 3 до 4 pp. & 1116 & 14,2 \\
\hline до 1 року & 897 & 11,4 \\
\hline від 4 до 5 pp. & 873 & 11,1 \\
\hline від 6 до 7 pp. & 589 & 7,5 \\
\hline від 5 до 6 pp. & 542 & 6,9 \\
\hline від 7 до 8 pp. & 488 & 6,2 \\
\hline від 8 до 9 pp. & 346 & 4,4 \\
\hline від 9 до 10 pp. & 220 & 2,8 \\
\hline від 10 до 11 pp. & 205 & 2,6 \\
\hline від 11 до 12 рр. & 71 & 0,9 \\
\hline від 12 до 13 рр. & 55 & 0,7 \\
\hline від 13 до 14 pp. & 31 & 0,4 \\
\hline від 14 до 15 pp. & 23 & 0,3 \\
\hline від 15 до 16 pр. & 18 & 0,1 \\
\hline від 16 до 17 pp. & 8 & 0,1 \\
\hline від 17 до 18 pp. & 7 & 0,1 \\
\hline Всього & 7866 & - \\
\hline
\end{tabular}


Таблиия 3 Породне співвідношення захворілих собак

\begin{tabular}{|l|c|c|}
\hline \multicolumn{1}{|c|}{ Порода } & Кількість & $\mathbf{\%}$ \\
\hline Безпородні собаки & 1644 & 20,9 \\
\hline Німецька вівчарка & 1093 & 13,9 \\
\hline Ротвейлер & 590 & 7,5 \\
\hline Метис Порода & 448 & 5,7 \\
\hline \multicolumn{1}{|c|}{ Пекінес } & Кількість & $\mathbf{\%}$ \\
\hline Англійський кокер-спанієль & 401 & 5,1 \\
\hline Такса & 228 & 2,9 \\
\hline Кавказька вівчарка & 214 & 2,7 \\
\hline Стафордширський тер'єр & 210 & 2,7 \\
\hline Лабрадор & 207 & 2,6 \\
\hline Середньоазійська вівчарка & 203 & 2,6 \\
\hline Пудель & 199 & 2,5 \\
\hline Шарпей & 195 & 2,5 \\
\hline Російський спанієль & 149 & 1,9 \\
\hline Боксер & 138 & 1,8 \\
\hline Дратхаар & 130 & 1,7 \\
\hline Американський кокерспанієль & 126 & 1,6 \\
\hline Доберман & 100 & 1,3 \\
\hline Лайка & 88 & 1,1 \\
\hline Чау-чау & 87 & 1,1 \\
\hline Інші породи & 79 & 1,0 \\
\hline Всього & 1337 & 17,0 \\
\hline
\end{tabular}

\section{Висновки}

Епізоотологічним моніторингом бабезіозу собак у м. Полтава за 2007-2016 роки визначено, що означена інвазія реєструється впродовж всього року, при цьому взимку зустрічаються лише поодинокі випадки, а також суттєве зниження кількості випадків у спекотні літні місяці. Загалом відмічається виразна сезонна динаміка 3 двома піковими періодами: квітень, вересень-жовтень. Весняний пік характеризується більшою кількістю захворювань, порівняно 3 осіннім. Серед захворілих собак самці переважають самок на $20 \%$. Найбільше захворюють собаки віком від 2 до 3 років (11,1-16\%). Визначено стійку тенденцію, щодо зниження сприйнятливості до бабезіозу з віком. Стосовно породного співвідношення захворюваності - найбільше захворюють безпородні собаки (20,9\%) та німецькі вівчарки $(13,9 \%)$ й ротвейлери $(7,5 \%)$.

Перспективами подальших досліджень є створення, на основі отриманих даних епізоотологічного моніторингу, стратегії профілактичних заходів щодо максимального зниження захворюваності собак на бабезіоз. Також, на наш погляд, результати 9-річних досліджень мають науковий інтерес для паразитологів гуманної та ветеринарної медицини, що вивчають бабезіози й інші захворювання людей і тварин, що передаються кліщами.

\section{Бібліографічні посилання}

Halat, V.F., Prus, M.P., Paskhalova, L.V. (2000). Klinichni oznaky ta rezultaty doslidzhen krovi sobak, khvorykh na babezioz. Vet. medytsyna Ukrayiny. 6, 28-29 (in Ukrainian).

Mokryy, Y.O., Prykhodko, Y.O., Kurman, A.F. (2009). Porodna, vikova i stateva spryynyatlyvist sobak do zakhvoryuvannya na babezioz m. Poltava. Problemy zooinzheneriyi ta veterynarnoyi medytsyny: zbirnyk naukovykh prats Kharkivskoyi derzhavnoyi zooveterynarnoyi akademiyi. 19(2), 207-213 (in Ukrainian).

Prus, M.P. (2006). Babezioz sobak (epizootolohiya, patohenez ta zakhody borotby): dys. doktora vet. nauk. 279 (in Ukrainian).

Prus, M.P. (2000). Deyaki pytannya epizootolohiyi babeziozu sobak za danymy veterynarnoyi kliniky «Fauna-servis». Visnyk BDAU. 11, 100-103 (in Ukrainian).

Prus, M.P., Berezovskyy, A.V., Halat, V.F. (2002). Diahnostyka ta zakhody borotby $\mathrm{z}$ babeziozom sobak. Rekomendatsiyi dlya derzhavnykh pidpryyemstv vetmedytsyny, laboratoriy, pryvatnykh klinik. - K. Vydavnychyy tsentr NAU, 6-7 (in Ukrainian).

Semenko, O.V. (2007). Udoskonalennya metodiv zazhyttyevoyi diahnostyky babeziozu sobak: avtoref. dys. na zdobuttya nauk. stupenya kand. vet. nauk: spets: 16.00.11 «Parazytolohiya, helmintolohiya». 21 (in Ukrainian).

Bowman, D.D., Fogarty, E.A. (2003). Parasitology: Diagnosticsm in Dogs and Cats. Wilmington, Gloyd Group.

Garcia, L.S., Bullock-Iacullo, S.L., Fritsche, T.R. (2000). Laboratory diagnosis of blood-borne parasitic diseases; Approved guideline. Clinical and laboratory standards institute. 20(12), 36.

Стаття надійшла до редакиії 13.02.2017 